\title{
APLIKASI KOMPUTASI KIMIA DALAM ANALISIS HUBUNGAN KUANTITATIF STRUKTUR-AKTIVITAS (HKSA) DARI SENYAWA AKTIF ANTIBAKTERI ANALOG N-ALKIL IMIDAZOL PADA BAKTERI (Staphilococcus aureus) DENGAN PARAMETER ELEKTRONIKMETODE AUSTIN MODEL (AM 1)
}

\author{
Rizqi Nur Azizah, Gemini Alam, Yusnita Rifai, Christiana Lethe \\ Fakultas Farmasi Universitas Hasanuddin \\ Email : rizqinurajijah@gmail.com
}

\begin{abstract}
A quantitative structure activity relationship study on a series of $N$-alkyl imidazole analogues using combination of various atomic descriptors and molecular descriptors have been investigated. The research was aimed to obtain mathematic equation Quantitative Structure-Activity Relationship of N-alkyl Imidazole analougues as antibacterial agents at bacteria Staphilococcus aureus with electronic parameters used semiempiric Austin Model 1 (AM1) method .Several statistical expressions were developed using stepwise multiple liner regression analysis. The best quantitative structure activity relationship models were further validated by leaveone-out method of cross-validation. The study revealed that the atomic net charges of $C_{2} \& C_{3}$,E-Homo,E-lumo,dipole moment $(\boldsymbol{\mu})$, and Total Energy $\left(\boldsymbol{E}_{T}\right)$ contributed positively, and atomic net charges of $C_{1}, N_{1}, \& N_{2}$, Binding Energy $\left(E_{b}\right), R M S$ Gradient (RMS), and Elecrtonic Energy $\left(\boldsymbol{E}_{e}\right)$ contributed negatively. The quantitative structure activity relationship study provides important structural insights in designing of potent antibacterial agents. Several alternative models which have possibility to express the correlation betwen biological activity and electronic parameters, "The best model" is represented by a linear function of activity versus atomic net charges of $C_{2} \& C_{3}$ and E-Homo, E-lumo,dipole moment $(\boldsymbol{\mu})$, and Total Energy $\left(\boldsymbol{E}_{e}\right)$ is axpressed by:

$\log (1 / C)=114,614( \pm 28,461)+505,362( \pm 149,739) q C_{2}+247,641( \pm 47,025) q C_{3}+$ $0,819( \pm 0,379)$ E-Homo $+93,404( \pm 25,997)$ E-Lumo $+-24,982( \pm 6,066) \mu+$ $-0,002( \pm 0,000) . E_{T}$
\end{abstract}

The cross validation analisys give minimal value of PRESS $=106,231$ and $S E P=$ 3,435

Key Words : QSAR, antibacterial, n-alkyl imidazole, Cross Validation Methods

\section{PENDAHULUAN}

Kimia

mempresentasikan struktur molekul

sebagai model numerik dan

merangsang perilaku dengan

persamaan kuantum dan fisika klasik.
Program software yang tersedia mendorong ilmuwan untuk menghasilkan dengan mudah dan menyajikan data molekul termasuk geometrik, energi dan sifat-sifat yang terkait (seperti elektronik, 
Aplikasi Komputasi Kimia Dalam Analisis Hubungan Kuantitatif Struktur-Aktivitas (Hksa) Dari Senyawa Aktif Antibakteri

spektroskopik, dan sifat lainnya). Kimia komputasi dapat menghasilkan gambaran struktur dalam berbagai model dan mempunyai aktifitas yang sama dengan penyamaan kuantum dari fisika klasik. Suatu studi dalam kimia medisinal yang banyak menggunakan metode komputasi kimia adalah studi QSAR (Quantitative Structure-Activity Relationship) atau HKSA (Hubungan Kuantitatif StrukturAktifitas).

HKSA merupakan metode untuk membuat suatu hubungan antara struktur dan aktifitas bahan obat dari berbagai deskriptornya. Deskriptor-deskriptor fisikakimia meliputi beberapa parameter termasuk hidrofobisitas atau lipofilisitas, topologi, elektronik dan sterik, yang dilakukan secara empirik atau yang lebih baru dengan metode komputasi. HKSA digunakan dalam pengukuran aktifitas bahan kimia dan pengujian biologis. HKSA sekarang diterapkan dalam berbagai disiplin ilmu dengan banyak menyinggung kedesain obat dan penilaian resiko lingkungan.

HKSA berusaha untuk menemukan hubungan yang konsisten diantara variasi pada nilai dan sifatsifat molekul dan aktivitas biologik untuk rangkaian campuran sehingga aturan ini dapat digunakan untuk mengevaluasi identitas kimia yang baru yang selanjutnya dapat membantu peneliti dalam mensintesis senyawa obat. Kimia komputasi dapat menghasilkan gambaran struktur molekul dalam berbagai model dan mempunyai aktifitas yang sama dengan penyamaan kuantum dari fisika klasik. Perkembangan kimia komputasi, terutama dalam penerapan perhitungan kimia kuantum yang berlangsung dengan pesat memungkinkan untuk dilakukannya pemodelan molekul dan eksplorasi sifat fisikakimia suatu struktur molekul. Metode kimia kuantum yang sering digunakan dalam perhitungan senyawa organik adalah metode semiempiris Austin Model 1 (AM1) yang dapat diterapkan dalam analisis HKSA menggunakan metode Hansch. Asumsi mendasar dari HKSA adalah bahwa terdapat hubungan kuantitatif antara mikroskopik (Struktur Molekul) dan sifat makroskopis / empiris (aktivitas biologis) dari suatu molekul. Istilah struktur tidak hanya terbatas pada pengertian pengaturan ruang dan hubungan antar atom dalam molekul saja, tetapi juga termasuk sifat fisika dan kimia yang melekat pada susunan tersebut.

Resistensi pada bakteri patogen untuk standar terapi antibiotik 
Aplikasi Komputasi Kimia Dalam Analisis Hubungan Kuantitatif Struktur-Aktivitas (Hksa) Dari Senyawa Aktif Antibakteri

menjadi masalah utama kesehatan diseluruh dunia. Insiden MultidrugResistant bakteri gram positif meningkat, dan infeksi yang disebabkan oleh bakteri Staphilococcus aureus, enterococcus, dan pneumococcus adalah masalah. Sehingga timbul keinginan untuk menemukan suatu senyawa baru yang memiliki aktifitas antibakteri yang mungkin berasal dari golongan antibakteri yang telah diketahui sebelumnya yang dapat menyerang bakteri patogen yang sekarang telah resisten.

Sebagai contoh metisilin yang dahulu sangat sensitif terhadap bakteri Staphilococcus aureus sekarang sudah tidak digunakan lagi sejak insiden Meticillin Resistant Staphilococcus Aureus sehingga harus dibasmi dengan vankomisin atau siprofloksasin. Imidazol atau 1,3 diazol adalah suatu senyawa organik aromatik heterosiklik, dikelompokkan kedalam golongan alkaloid dengan rumus molekul $\mathrm{C}_{3} \mathrm{H}_{4} \mathrm{~N}_{2}$. Imidazol adalah kelompok senyawa heterosiklik dengan struktur cincin yang sama tetapi subtituennya bervariasi. Banyak obat yang memiliki cincin imidazol memiliki aktivitas antifungi.

Turunan $\mathrm{N}$-alkil imidazol telah diidentifikasi sebagai kandidat senyawa antibakteri yang potensial, juga telah dilaporkan bahwa $\mathrm{N}$-alkil imidazol dengan banyak variasi struktur yang sederhana mampu menghambat oksidasi mikrosomal dan menyebabkan keracunan sel bakteri.

Dalam penelitian ini akan dipelajari salah satu aspek dalam perancangan suatu obat khususnya yang memanfaatkan komputer berdasarkan teori kimia kuantum. Senyawa yang digunakan sebagai kajian adalah Senyawa aktif Antibakteri analog $\mathrm{N}$-alkil imidazol pada bakteri Staphilococcus aureus. Senyawa analaog $\mathrm{N}$-alkil imidazol diperoleh dari beberapa senyawa yang memiliki rumus struktur inti sama namun terdapat perbedaan pada subtituennya. Adanya perbedaan subtituen pada tiap senyawa menyebabkan adanya perbedaan aktivitas biologis.

Lingkup bahasan dari penelitian ini dibatasi pada analisis hubungan kuantitatif antara struktur elektronik dengan aktivitas biologis dari senyawa aktif antibakteri senyawa analog N-alkil imidazol. Tujuan penelitian ini adalah menentukan model persamaan matematis Hubungan Kuantitatif Struktur-Aktivitas dari senyawa aktif antibakteri analog $\mathrm{N}$-alkil imidazol terhadap bakteri 
Aplikasi Komputasi Kimia Dalam Analisis Hubungan Kuantitatif Struktur-Aktivitas (Hksa) Dari Senyawa Aktif Antibakteri

Staphilococcus aureus dengan parameter elektronik menggunakan metode semiempiris Austin Model 1 (AM1).

\section{METODE PENELITIAN}

\section{A. Data dan Alat yang digunakan}

Adapun data yang digunakan berupa data set struktur dan aktifitas senyawa aktif antibakteri analog $\mathrm{N}$-alkil imidazol pada bakteri Staphilococcus aureus dari literatur.

Adapun alat yang digunakan keras berupa satu set komputer yang mampu melakukan perhitungn kimia komputasi dengan spesifikasi : Processor tipe Pentium 4- 2,6 GHz ( Intel囚), RAM $256 \mathrm{MB}$, Harddisk $80 \mathrm{~GB}$, Perangkat lunak (software) sistim operasi WindowsTM XP Profesional, Perangkat lunak (Software) HyperChem® 7.5, Perangkat Lunak (Software) SPSS 12.0 for Windows

\section{B. Prosedur Penelitian}

\section{Optimasi Geometri}

Senyawa

yang

digunakan sebagai bahan penelitian dibuat struktur dua dimensi ( 2D ) menggunakan paket program HyperChem $\AA^{\circ}$. Selanjutnya dilakukan penambahan atom $\mathrm{H}$ untuk melengkapi strukturnya dan dibentuk menjadi struktur tiga dimensi (3D).

Struktur yang terbentuk dioptimasi geometri menggunakan metode AM1 dengan algoritma PolakRibbiere. Struktur yang telah teroptimasi disimpan sebagai file.hin.

\section{Perhitungan Prediktor}

Dilakukan perhitungan single point dengan menggunakan paket program HyperChem ${ }^{\circledR}$ pada struktur yang teroptimasi untuk memperoleh parameter elektronik $(\sigma)$ berupa muatan bersih atom (q) yang terdapat pada molekul (7).

\section{Analisis Statistik}

Dilakukan analisis
regresi multilinier dengan
muatan bersih atom sebagai
variabel bebas terhadap
senyawa aktif antibakteri analog
N-alkil imidazol pada bakteri
Staphilococcus aureus yang
dinyatakan sebagai log (1/MIC)
sebagai variabel tergantung.

Pemilihan

model persamaan terbaik dilakukan dengan mempertimbangkan parameter statistik F, R2, SE 
Aplikasi Komputasi Kimia Dalam Analisis Hubungan Kuantitatif Struktur-Aktivitas (Hksa) Dari Senyawa Aktif Antibakteri

dan Predicted Sum Squares

(PRESS) (11). Validasi model persamaan terbaik dilakukan dengan metode validasi silang. Model persamaan terbaik yang diperoleh digunakan untuk memprediksi harga aktifitas anti bakteri teoritif setiap senyawa.

\section{HASIL PENELITIAN}

Dalam penelitian ini diperoleh hasil berupa model persamaan terbaik berdasarkan parameter PRESS sebesar 106,231, $R^{2}$ vs sebesar 0,944, SEP sebesar 3,435 dan $F_{v s}$ sebesar 21,579 dengan persamaan

$$
\begin{aligned}
\log (1 / C)= & 114,614( \pm 28,461)+505,362 \\
& \pm 149,739) \mathrm{qC}_{2}+247,641 \\
& ( \pm 47,025) q \mathrm{CC}_{3}+0,819 \\
& ( \pm 0,379) \text { E-Homo }+93,404 \\
& ( \pm 25,997) \text { ELumo }+-24,982 \\
& ( \pm 6,066) \text { momen dipol }+ \\
& -0,002( \pm 0,000) \text { E total }
\end{aligned}
$$

\section{PEMBAHASAN}

\section{Tinjauan Struktur Elektronik} Senyawa Aktif Antibakteri

Semua senyawa dalam seri senyawa analog $n$-alkil imidazol diperoleh dari literatur. Sebelum dilakukan perhitungan untuk memperoleh deskriptor, setiap senyawa dari seri analog $n$-alkil imidazol dioptimasi geometri terlebih dahulu dengan menggunakan metode semiempiris
AM1, yang bertujuan untuk menyeragamkan keadaan sistim melalui kondisi yang terkendali dan kriteria yang ditentukan.

Dalam kimia kuantum penemuan metode AM 1 adalah sangat berguna. Banyak prosedur perhitungan yang belum juga teliti, walaupun dapat dipakai dalam batasan molekul sederhana, contohnya adalah metode medan keajegan diri diri orbital molekuler (Molekuler Orbital Self Consistent Field $=$ MOSCF ab initio, yang memerlukan waktu yang lama dalam perhitungan. Pada pendekatan AM1 sudah cukup serasi untuk digunakan sebagai suatu pikiran yang relatif sederhana untuk perhitungn yang diinginkan. Penggunaan Komputer dapat digunakan untuk menaikkan ketelitian hasil yang diinginkan dalam eksperimen $(21,22)$. Setelah diperoleh struktur terstabil dilakukan perhitungan single point energy untuk mencatat data perhitungan. Data perhitungan meliputi energi dan struktur elektronik senyawa.

\section{Regresi Multilinier}

Langkah berikutnya Dilakukan analisis regresi multilinier dengan muatan netto atom (q) pada posisi 
$\mathrm{C}_{1}, \mathrm{~N}_{1}, \mathrm{C}_{2}, \mathrm{C}_{3}$, dan $\mathrm{N}_{2}$, energi total $\left(\boldsymbol{E}_{T}\right)$, energi ikat $\left(\boldsymbol{E}_{b}\right)$, Energi Elektronik $\left(\boldsymbol{E}_{\boldsymbol{e}}\right), \mathrm{RMS} \quad$ Gradient (RMS), dan momen dipol $(\boldsymbol{\mu})$ sebagai variabel bebas terhadap senyawa aktif antibakteri analog $\mathrm{n}$ alkil imidazol terhadap bakteri Staphilococcus aureus yang dinyatakan sebagai log (1/MIC) sebagai variabel tergantung.

Perangkat lunak yang digunakan untuk mengolah data pada penentuan model persamaan terbaik dengan regresi multilinier pada penelitian ini adalah SPSS for Window Ver. 12 dengan menggunakan metode regresi multilinier stepwise, yaitu metoda regresi reduksi bertahap. Dengan menggunakan teknik pengujian data leave-one-out, dipilih model persamaan terbaik HKSA dengan nilai $R$ atau $R^{2}$ mendekati 1 atau -1 , nilai SE lebih kecil, jika nilai $F$ hitung lebih besar daripada $F$ tabel maka hipotesa dapat diterima. Sebaliknya, jika $\mathrm{F}$ hitung sama atau lebih kecil dari $F$ tabel maka hipotesa ditolak, nilai signifikansi lebih kecil $(<0,05)$, nilai PRESS lebih kecil dan SEP lebih kecil.

\section{Penggunaan Deskriptor Atomik dan Molekuler}

Kajian HKSA menggunakan deskriptor yang diturunkan dari perhitungan kimia kuantum seperti yang tercantum dalam tabel 1 .

Tabel 1. Daftar deskriptor yang digunakan dalam penelitian ini

\begin{tabular}{|c|c|c|}
\hline Simbol & Satuan & Defenisi \\
\hline$q_{C 1}$ & Coulomb & Muatan atomik netto atom $C 1$ \\
\hline$q_{N 1}$ & Coulomb & Muatan atomik netto atom $N 1$ \\
\hline$q_{C 2}$ & Coulomb & Muatan atomik netto atom $C 2$ \\
\hline$q_{C 3}$ & Coulomb & Muatan atomik netto atom $\mathrm{C} 3$ \\
\hline$q_{N 2}$ & Coulomb & Muatan atomik netto atom $\mathrm{N} 2$ \\
\hline Еномо & $\mathrm{eV}$ & $\begin{array}{l}\text { Tingkat energi orbital molekul tertinggi yang terisi } \\
\text { elektron }\end{array}$ \\
\hline $\mathrm{E}_{\text {LUMO }}$ & $\mathrm{eV}$ & $\begin{array}{l}\text { Tingkat energi orbital molekul terendah yang tak } \\
\text { terisi elektron }\end{array}$ \\
\hline $\mathrm{E}_{T}$ & kkal.mol & Energi total \\
\hline $\mathrm{E}_{b}$ & kkal.mol & Energi ikat \\
\hline & kkal.mol & Energi elektronik \\
\hline RMS Gradient & kkal.mol & Gradien akar kuadrat \\
\hline$\mu$ & Debye & Momen dipol \\
\hline
\end{tabular}


Aplikasi Komputasi Kimia Dalam Analisis Hubungan Kuantitatif Struktur-Aktivitas (Hksa) Dari Senyawa Aktif Antibakteri

\section{Model Persamaan Terbaik}

Melalui perhitungan statistik analisis regresi multilinier dengan bantuan komputer, didapat persamaan Hubungan Kuantitatif
Struktur-aktivitas senyawa aktif antibakteri analog n-alkil imidazol terhadap bakteri Staphilococcus aureus dengan menggunakan parameter eletronik.

Tabel 2. Model persamaan terpilih hasil regresi multilinier menggunakan deskriptor atomik metode AM1

\begin{tabular}{|c|c|c|c|c|c|c|c|c|}
\hline Model & Deskriptor & $\mathbf{n}$ & $\mathbf{m}$ & $\mathbf{R}$ & $\mathbf{R}^{2}$ & SE & $\mathbf{F}$ & Sig. \\
\hline 260 & $\begin{array}{l}\text { E-elektronik,qN2,E-Homo,qC3, } \\
\text { Momen Dipol, E-Lumo, E-Total }\end{array}$ & 17 & 7 & 0,965 & 0,931 & 0,416 & 17,431 & 0,000 \\
\hline 275 & $\begin{array}{l}\text { E - elektronik, qC2, E Homo, } \\
\text { qC3, Momen Dipol, E-Lumo, } \\
\text { E-Total }\end{array}$ & 17 & 7 & 0,971 & 0,944 & 0,376 & 21,579 & 0,000 \\
\hline 277 & $\begin{array}{l}\text { E-elektronik, RMS Gradient, E- } \\
\text { Homo, qC3, Momen Dipol, E- } \\
\text { Lumo ,E-Total }\end{array}$ & 17 & 7 & 0,964 & 0,930 & 0,420 & 17,042 & 0,000 \\
\hline 278 & $\begin{array}{l}\text { E-Elektronik, RMS Gradient, E- } \\
\text { Homo, Momen Dipol, E-Lumo, } \\
\text { E-Binding, qN2 }\end{array}$ & 17 & 7 & 0,953 & 0,908 & 0,482 & 12,659 & 0,001 \\
\hline 285 & $\begin{array}{l}\text { E-Elektronik, qN1, qC2, E- } \\
\text { Homo, qC3, Momen Dipol,E- } \\
\text { Lumo, E-Total }\end{array}$ & 17 & 8 & 0,973 & 0,946 & 0,392 & 17,459 & 0,000 \\
\hline 287 & $\begin{array}{l}\text { E-Elektronik, RNS Gradient, E- } \\
\text { Homo, qC3, Momen Dipol, E- } \\
\text { Lumo, qC2 }\end{array}$ & 17 & 7 & 0,947 & 0,897 & 0,509 & 11,198 & 0,001 \\
\hline 293 & $\begin{array}{l}\text { E-Elektronik, qN1, RMS } \\
\text { Gradient, E-Homo, qC3, } \\
\text { Momen Dipol, E-Lumo, qC2 }\end{array}$ & 17 & 8 & 0,949 & 0,901 & 0,530 & 9,080 & 0,003 \\
\hline 294 & $\begin{array}{l}\text { E-Binding, qN2, E-Homo, qC3, } \\
\text { Momen Dipol, E-Lumo, E- } \\
\text { Elektronik }\end{array}$ & 17 & 7 & 0,961 & 0,924 & 0,436 & 15,709 & 0,000 \\
\hline 297 & $\begin{array}{l}\text { E-Elektronik, RMS Gradient, E- } \\
\text { Homo, Momen Dipol, E-Lumo, } \\
\text { E-Total, qN2 }\end{array}$ & 17 & 7 & 0,958 & 0,918 & 0,453 & 14,466 & 0,000 \\
\hline 298 & $\begin{array}{l}\text { E-Elektronik, RMS Gradient, E- } \\
\text { Homo, qC3, Momen Dipol, E- } \\
\text { Lumo, E-Binding }\end{array}$ & 17 & 7 & 0,959 & 0,920 & 0,448 & 14,803 & 0,000 \\
\hline
\end{tabular}

$\mathrm{n}=$ jumlah data; $\mathrm{m}=$ jumlah variabel yang masuk dalam persamaan; $\mathrm{R}$ dan $\mathrm{R}^{2}=$ koefisien korelasi; $\mathrm{SE}=$ standar Error; $\mathrm{F}=$ kriteria Fisher hasil analisis ANOVA; Sig. = signifikansi $\mathrm{F}$ pada $95 \%$

Dari tabel 3 terlihat bahwa menghasilkan 10 model terpilih, penggunaan metode AM1 dimana deskriptor yang masuk dalam 
Aplikasi Komputasi Kimia Dalam Analisis Hubungan Kuantitatif Struktur-Aktivitas (Hksa) Dari Senyawa Aktif Antibakteri

persamaan berkisar 7-8. model persamaan terpilih dari penggunaan deskriptor atomik dan molekuler dengan metoda AM1 mempunyai nilai $R$ di sekitar 0,971 dan nilai $F$ lebih besar dari $F$ tabel yaitu $F$ hitung sebesar 21,579 .

Dengan memperhatikan nilai-nilai parameter tersebut, maka model persamaan yang diperkirakan sebagai model persamaan HKSA terbaik adalah model 275 dan 285. Namun untuk memutuskan model mana yang benarbenar terbaik, masih dijumpai beberapa kesulitan, mengingat model yang lainpun juga memiliki harga parameter statistik yang berdekatan sehingga model-model tersebut juga cukup berpeluang. Untuk menguji validitas model dalam kemampuan memprediksi aktivitas antibakteri senyawa lain diluar data fitting regresi, digunakan uji validasi silang (cross validation test). Uji validasi silang menggunakan teknik leave-one-out yaitu pada $\mathrm{n}$ buah data sebuah data dikeluarkan dari data fitting. Analisis regresi multilinier diulangi untuk data sebanyak ( $\mathrm{n}-1)$ dengan menggunakan deskriptor yang masuk dalam model persamaan yang akan diuji. Persamaan regresi yang didapatkan digunakan untuk memprediksi harga aktivitas antibakteri dari data yang dikeluarkan tadi. Proses berulang sampai semua data terprediksi. Pada penelitian ini akan terjadi 17 kali proses perhitungan dari 17 buah data untuk masing-masing model. Nilai PRESS (Preditced Residual Sum of Squares) dan parameter statistik uji validasi silang yang lain $\left(R^{2}{ }_{c v}\right.$, SEP dan $\mathrm{F}_{\mathrm{cv}}$ ) digunakan untuk menentukan model persamaan terbaik. Model yang mempunyai nilai PRESS terkecil, $\mathrm{R}_{\mathrm{cv}}^{2}$ yang terbesar (mendekati 1), SEP yang terkecil dan $F_{c v}$ yang terbesar merupakan model yang terbaik. Parameter statistik hasil uji validasi silang disajikan pada tabel 3 .

Tabel 3. Parameter statistik hasil validasi silang leave-one-out persamaan HKSA terbaik

\begin{tabular}{cccccc}
\hline Model & PRESS & $\mathbf{R}_{\text {cv }}^{2}$ & SEP & $\mathbf{F}_{\text {cv }}$ & $\mathbf{S i g}_{\text {cv }}$ \\
\hline 260 & 108,885 & 0,990 & 3,478267 & 130,572 & 0,000 \\
$\mathbf{2 7 5}$ & $\mathbf{1 0 6 , 2 3 1}$ & $\mathbf{0 , 9 9 0}$ & $\mathbf{3 , 4 3 5 6 0 6}$ & $\mathbf{1 3 3 , 8 6 7}$ & $\mathbf{0 , 0 0 0}$ \\
277 & 110,786 & 0,990 & 3,5084995 & 128,309 & 0,000 \\
278 & 115,199 & 0,990 & 3,394102 & 159,891 & 0,000 \\
285 & 106,032 & 0,991 & 4,640600 & 104,316 & 0,000 \\
287 & 108,391 & 0,990 & 3,470360 & 131,173 & 0,000 \\
293 & 108,391 & 0,990 & 3,470360 & 131,173 & 0,000 \\
294 & 123,339 & 0,989 & 3,51191 & 149,230 & 0,000 \\
297 & 109,345 & 0,990 & 3,485611 & 130,017 & 0,000 \\
298 & 123,339 & 0,989 & 3,511961 & 149,230 & 0,000 \\
\hline
\end{tabular}


Aplikasi Komputasi Kimia Dalam Analisis Hubungan Kuantitatif Struktur-Aktivitas (Hksa) Dari Senyawa Aktif Antibakteri

Nilai parameter yang tercetak tebal merupakan model "TERBAIK" dibandingkan model-model lain. Diperoleh model 275 sebagai model terbaik dengan harga PRESS sebesar 106,231, $R_{\text {cv }}^{2}$ sebesar 0,990, SEP sebesar 3,435 dan $F_{c v}$ sebesar 133,867. Secara lengkap, sebagai model persamaan terbaik adalah sebagai berikut :

$\log (1 / C)=114,614( \pm 28,461)+$ $505,362 \quad( \pm 149,739) \quad \mathrm{qC}_{2}$ $+247,641( \pm 47,025) \mathrm{qC}_{3}+$ $0,819( \pm 0,379)$ E-Homo + $93,404 \quad( \pm 25,997)$ ELumo $+$ $-24,982$ $( \pm 6,066)$ momen dipol +$0,002( \pm 0,000) E$ total

Dengan nilai $R=0,971, R^{2}=$ $0,944, \mathrm{SE}=0,376 \mathrm{~F}=21,579, \mathrm{Sig}=$ 0,000, PRESS $=106,231$ dan SEP $=$ 3,435

\section{Catatan : $\log (1 / C)=$ MIC KESIMPULAN}

Berdasarkan hasil pengolahan data dan hasil analisa yang telah dilakukan dalam penelitian ini dapat diperoleh beberapa kesimpulan :

1. Persamaan terbaik untuk HKSA pada senyawa aktif antibakteri analog $\mathrm{n}$-alkil imidazol terhadap bakteri Staphilococcus aureus adalah : $\log (1 / C)=114,614( \pm 28,461)+$ $505,362 \quad( \pm 149,739) \quad q_{2}+$ $247,641( \pm 47,025) \quad \mathrm{qC}_{3}+0,819$ $( \pm 0,379) \quad$ E-Homo $+93,404$ $( \pm 25,997)$ ELumo + $24,982( \pm 6,066)$ momen dipol + $0,002( \pm 0,000)$ E total

Dengan nilai PRESS $=106,231$ dan SEP $=3,435$

Catatan $: \log (1 / C)=$ MIC

2. Untuk memprediksi harga aktivitas biologis senyawa aktif antibakteri analog n-alkil imidazol hanya diperlukan muatan netto atom dari atom pada posisi C2 dan C3 dan muatan molekuler E-Homo, Elumo,momen dipol, dan E-total.

\section{DAFTAR PUSTAKA}

Richon, B., Allen, 1997, "An Introduction to QSAR Methodology", Network Science,http://www.netsci.org /Science/Compchem/feature 11.html diakses 7 Juli 2007,(hal 1-2)

Bevan, R., David, 2002, "QSAR And Drug Design", Network Science,http://www.netsci.org /Science/Compchem/feature 12.html diakses 7 Juli 2007,(hal 1-2)

Tahir, I. 2000, "Hubungan Kuantitatif Struktur Elektronik-Aktivitas Senyawa Turunan N,NDimetil-2-Bromo Fenil Etil Amina Menggunakan Metoda Validasi Silang", Tesis, Program Pascasarjana 
Aplikasi Komputasi Kimia Dalam Analisis Hubungan Kuantitatif Struktur-Aktivitas (Hksa) Dari Senyawa Aktif Antibakteri

Universitas Gadjah Mada, Yogyakarta,hal (1-36)

Kubinyi, H., 1993, QSAR; Hansch Analysis and Related Approaches, $\quad \mathrm{VCH}$ Verlagsgesellschaft,Weinhei $\mathrm{m},($ hal 5-20)

Sardjoko, 1993, Rancangan Obat, Gadjah Mada University Press, Yogyakarta,(hal 75$79,168)$

Nazneen,K.,2006,"QSAR Analysis of $\mathrm{N}$-alkyl Imidazole analogues as antibacterial agents", Indian Journal of Pharmaceutical Sciences Vol 68,

http://www.ijpsonline.com/arti cle,diakses 8 Juli 2007, (hal 341-346)

Ganiswarna,S.,"Farmakologi dan Terapi", Bagian Farmakologi Fakultas Kedokteran UI, Jakarta,(hal.573)

Nogrady,T.,1992, " Kimia Medisinal, Pendekatan secara Biokimia", Penerbit ITB,Bandung, (hal 52)

Reksohadiprodjo ,M., 1994 ," Pusat Penelitian Obat Masa Kini“, UGM Press, Yogyakarta,(hal 48)

Lee, K.W., Kwon, S.Y., Hwang, S., Lee, J.U., Kim, H, 1996, Quantitative StructureAktivity Relationships (QSAR) Study on C-7 Substituted Quinolone, Bull, Korean Chem Soc. 17,(hal.147-152)

Sembiring, R.K.,1995, Analisis Regresi, Penerbit Institut
Teknologi

Bandung,(hal 120-130)

Franke, R.,1984, Theoretical Drug Design Methods, Elsevier, Amsterdam (hal 582-590)

McFarland, J.W., Berger, C.M., Froshauer, S.A., Hayashi, S.F., Hecker, S.J., Jaynes, B.H., Jefson, M.R., Kamicker, B.J., Lipinski, C.A., Lundy, K.M., Reese, C.P., Macrolide Antibacterial Agents; InVitro and in Vivo potency against Pasteurella multocida, J. Med. Chem., (hal. 40,13401346)

Foye,W.,1995,"Prinsip-Prinsip Kimia Medisinal", Gadjah Mada University Press Yogyakarta,(hal.95)

,2006,"AM 1", From Wikipedia, the Free Encycopedia "http://en.wikipedia.org/wiki/A M1, diakses tanggal 7 Juli 2007, (hal 1)

Allinger,N.,1996,"HyperChem ${ }^{\circledR}$, Compu tational Chemistry", Hypercube Inc,Canada.(hal.7)

Dewar, M.J.S., Zoebish E.G., Healy E.F., Stewart J.J.P., 1985, AM 1: A New General Purpose Quantrum Mechanical Molecular Model, J. Am. Chem. Soc., vol 107

Siswandono,2000,"Kimia Medisinal", Airlangga University Press, Surabaya,(hal. 255)

Khadikar, P.V., Karmarkar, S., Agrawal, V.K., 1996, Quantum-Chemical Descriptors in QSAR/QSPR 
Aplikasi Komputasi Kimia Dalam Analisis Hubungan Kuantitatif Struktur-Aktivitas (Hksa) Dari Senyawa Aktif Antibakteri

Studies, J. Chem. Inf. Comput. Sci., 41,(hal.934 949).

,2003, HyperCheme ${ }^{\circledast}$ Release

7.5 for Windows, Hypercube Inc.Canada

,2003,SPSS ${ }^{\circledR} \quad 12.0 \quad$ For

Windows,SPSS Inc.Canada

Widiyantoro, P., 1997, Hubungan Kuantitatif Antara StrukturAktivitas pada N,N-Dimetil-2Bromo-Fenelitamin

Tersubstitusi menggunakan metode
PM3,Skripsi,FMIPA UGM, Yogyakarta

Santoso, S., 2000, Buku Latihan SPSS Statistik Parametrik, PT. Gramedia, Jakarta

Bohm,H.,2000,"Virtual Screening for Bioactive Molecules, Method and Principles in Medicinal Chemistry",Vol.10,WilleyVCH,(Hal.80-113)

Kier,L.,1997,"Teori Orbital Molekul Dalam Riset Obat", Gadjah Mada University

Press,Yogyakarta.(hal 25-49) 